Mexican Journal of Biotechnology 2021, 6(2):61-85

Journal homepage:www.mexjbiotechnol.com

Research Centre for Biological Sciences

(CICB), Autonomous University of

Tlaxcala, Mexico. All rights reserved

ISSN:2448-6590

ORIGINAL RESEARCH

\title{
Genetic characterization of the microbiota of artisan fresh cheese from the Papaloapan region
}

\section{Caracterización genética de la microbiota del queso fresco artesanal de la región del Papaloapan}

Miguel A. García-Muñoz ${ }^{1}$, Nancy Cruz-Velazco¹, América Chávez-Martínez², Cirilo Nolasco-Hipólito ${ }^{3} \&$ José Abad-Zavaleta ${ }^{3^{*}}$

1'División de Estudios de Posgrado, Universidad del Papaloapan, Circuito Central No. 200, Col. Parque Industrial, Tuxtepec, Oaxaca, C.P. 38301, Mexico.

${ }^{2}$ Facultad de Zootecnia y Ecología, Universidad Autónoma de Chihuahua. Perif. Francisco. R. Almada Km 1, col. Zootecnia, Chihuahua, Chih., C.P. 33820, Mexico

${ }^{3}$ Instituto de Biotecnología, Universidad del Papaloapan, Circuito Central No. 200, Col. Parque Industrial, Tuxtepec, Oaxaca, C.P. 38301, Mexico.

${ }^{*}$ Corresponding author

E-mail address: jabad@unpa.edu.mx (J. Abad-Zavaleta).

Article history:

Received: 6 February 2021 / Received in revised form: 15 March 2021 / Accepted: / 17 March 2021 / Published online: 1 April 2021.

https://doi.org/10.29267/mxib.2021.6.2.61

\begin{abstract}
The population of the Papaloapan region consume artisan fresh cheeses and no pathogen outbreaks have been reported recently. The microbiota is responsible to develop desirable characteristics of cheeses and undesirable characteristics due to the presence of certain pathogens microorganisms. Therefore, to identify the microorganisms of fresh cheeses is an important issue for the producers, consumers, and authorities. 11 Artisan fresh cheese samples from the Papaloapan region were collected in the summer and 11 samples in winter to characterize their microbiota. Traditional microbial techniques were used to identify the fungus and the amplification of the 16S rRNA gene and PCR-denaturing gradient gel electrophoresis (DGGE)
\end{abstract}


method was used for bacteria identification. For all the samples, the presence of aerobic mesophiles, Streptococcus mesophiles and thermophiles, Lactobacillus mesophiles, Leuconostoc, total coliforms, Staphylococcus aureus, molds, and yeasts were identified. The complexity and variety of microorganisms in the summer and winter seasons samples were not significantly different. In conclusion, all samples of fresh artisan cheeses were under high microbial loads. Lactic Acid Bacteria (LAB) were in a typical load, as established by the quality and safety standards in the food industry. Conversely, pathogenic bacteria exceeded this limit.

The microorganisms present in the fresh artisanal cheeses of the Papaloapan region were identified with precision, regarding the count and their diversity. A recommendation for the cheese manufacturers is to prepare starter cultures by selecting the appropriate microorganisms to produce the desirable characteristics such as aroma and flavor and reduce the risk of microbial infections by using pasteurized milk.

Keywords: Fresh artisan cheese, cheese microbiota, lactic acid bacteria, genetic characterization, starter culture, raw milk.

\section{RESUMEN}

La población de la región de Papaloapan consume quesos frescos artesanales y sin brotes de patógenos recientemente. La microbiota es responsable del desarrollo de características deseables de los quesos e indeseables debido a microorganismos patógenos. Identificar estos microorganismos es un tema importante para los productores, consumidores y autoridades. Se recolectaron 11 muestras de queso fresco artesanal de la región de Papaloapan en verano y 11 muestras en invierno para caracterizar su microbiota. Se utilizaron técnicas microbianas tradicionales para identificar los hongos y se utilizó la amplificación del gen 16S rRNA y el método de electroforesis en gel de gradiente desnaturalizante por PCR (DGGE) para identificar bacterias. Se identificaron mesófilos aeróbicos, Streptococcus mesófilos y termófilos, Lactobacillus mesófilos, Leuconostoc, coliformes totales, Staphylococcus aureus, mohos y levaduras. La complejidad y variedad de microorganismos identificados en verano y en invierno no fueron significativamente diferentes. En conclusión, todas las muestras presentaron alta carga microbiana. Las bacterias ácido láctico (LAB) mostraron una carga típica, de acuerdo con estándares de calidad y seguridad de la industria alimentaria. Contrariamente, las bacterias patógenas superaron este límite. Los microorganismos presentes en los quesos frescos artesanales fueron identificados con precisión, en su conteo y diversidad. Una recomendación para los fabricantes es utilizar cultivos iniciadores apropiados y leche pasteurizada para producir las características deseables, como aroma y sabor, y reducir riesgos de infecciones microbianas.

Palabras clave: Queso artesanal Fresco, microbiota de queso, bacterias ácido lácticas, caracterización genética, cultivo iniciador, leche bronca. 


\section{INTRODUCTION}

Cheese is one of the oldest and most popular food products made by humankind. Cheeses are globally well accepted as a classic product of the human diet. The nutritional, functional, sensorial, and texture characteristics of cheeses differ in each type. There are about 2,000 cheese varieties worldwide and they can be classified from a number of viewpoints, e.g. according to: milk origin, curd formation, texture or consistence, and fat content (Belitz et al., 2004). The cheese making process has undergone relevant changes throughout history, from an empirical art to an industrial technology with strong scientific bases. Cheese processing is an important study area to elucidate and understand the phenomena that have an impact during its production, formulation, and storage. Besides, the effects such as taste, aroma, color, and texture caused by microorganisms on the quality of the final product are also essential. In general, raw milk is the primary ingredient used to produce artisan cheeses in many regions. The microbial group of cheeses that has a significant presence or greater industrial interest is Lactic Acid Bacteria (LAB). Some other genera like pathogenic microorganisms are also present (Cremonesi et al., 2020) (SIAP, 2019).

In 2019, Mexico produced 476,927 tons of cheese of which 89,557 tons were fresh cheeses (SIAP, 2020). The Papaloapan region has potential as a milk producer due to a lower production cost, as compared to those of temperate zone milk-based livestock production intensive systems. The Papaloapan region produces raw cow's milk based products for the local and regional markets. Cheese agribusiness stems from the need to preserve the milk, which is affected by the content of dry matter and fat (PopovićVranješ et al., 2018). The microbiota present in artisan cheeses is extraordinarily complex and occasionally, the presence of pathogenic microorganisms affects their hygienic and sensorial quality (Yeluri Jonnala et al., 2018). As a result, there are variations between cheeses, although they originate from the same geographical area. To avoid this problem, manufacturers have started to use pasteurized milk. However, industrial cheeses develop less intense flavors than those made with raw milk. Pasteurized milk directly influences the cheese's sensorial characteristics such as taste, aroma, color, and texture (Tadjine et al., 2020). The modification of the characteristics, impaired by the pasteurized milk, results in less acceptance by the consumer. The local population prefer the characteristics produced by the natural microorganism. Therefore, industrial cheeses are less attractive and less accepted by consumers in the region, even when the standardization of the product assures the enhancing of sanitary conditions.

Most of the small enterprises use raw milk to produce artisanal fresh cheeses (TorresLlanez et al., 2006). There is not a characterization of the microorganisms present in the cheeses manufactured in Papaloapan region, where the raw milk is also used. However, there are reports on the characterization of cheeses from other regions. For instance, Torres-Llanez, et al. (2006), used raw milk to produce fresh cheese in Hermosillo, Sonora. LAB was the major microbial group in artisanal Mexican Fresh cheeses at the three incubation temperatures studied. The temperature is an important parameter that 
promotes the proliferation of microorganism. Research works reported the analysis of the microbiota of cheeses produced during different seasons. During summer and winter seasons to effect on the microorganism count and the diversity could be significant. Aldrete-Tapia, et al., (2018) reported the characterization of bacterial communities in Mexican artisanal raw milk "Bola de Ocosingo" Cheese by HighThroughput Sequencing. They analyzed Twenty-four samples from three producers in the state of Chiapas, Mexico, collected at dry (March-June) and rainy seasons (AugustNovember). In the Bola de Ocosingo cheese production, S. thermophilus, L. lactis, $L$. helveticus, L. delbrueckii and L. plantarum dominated during the cheese processing, all reported with potential probiotic effect. In addition, they found that prevalence of these bacteria differed across manufacturers and seasons which could account to differences in final product quality (Aldrete-Tapia et al., 2018). In similar study, the bacterial community of the artisanal Adobera cheese from Los Altos de Jalisco was described through high-throughput sequencing of 16S rRNA gene libraries. Samples were collected in two different seasons (dry and rainy). Firmicutes and Proteobacteria were the most abundant phyla, strongly represented by the Streptococcaceae, Enterobacteriaceae and Lactobacillaceae families, and core bacteria genera such as Streptococcus spp., Lactococcus spp., and Lactobacillus spp. Undesirable bacteria, including Pseudomonas spp. and Acinetobacter spp., were also detected in raw milk but almost undetectable at the end of the cheese manufacturing process (RuvalcabaGómez et al., 2020). Similarly, the season for sampling was considered to characterize the artisanal Aro cheese. Then, the samples were collected in April, May and June, since the highest temperatures in the region are recorded at this time of year (González-Montiel \& Franco-Fernández, 2015).

As a result of the above stated, it is valuable to identify the microorganisms that make up the fresh cheese microbiota in the Papaloapan region. Adversely, the pathogenic strains that incur affect not only the sanitary quality of the cheese but also the beneficial properties (Murphy et al., 2016). The isolation and characterization of the latter could allow the addition of pasteurized milk for cheese making, thus providing the sensorial characteristics of fresh artisan cheese.Therefore, this work aimed to characterize the microbiota of fresh cheeses produced in the Papaloapan region and referred exclusively to cheeses made from cow's raw milk. Although is not an objective of the research, the results could help to enhance the manufacturing process and at the same time, to inform about the existing risk to consuming this kind of products.

\section{MATERIALS AND METHODS}

Disregarding the season and place of sampling, all the protocols applied were the same for the 22 samples studied.

\subsection{Cheese Sampling}

A total of 22 artisan fresh cheese samples made with raw milk were collected from four places in the Papaloapan region. The samples were taken in two different seasons, 11 
cheese samples were collected in summer in July (2014) and 11 in winter in January (2015). All the analysis in the samples were performed by two replications.

Farms with the highest cheese production were selected as sampling sites according to statistical analysis. The samples collected were as follows: two cheese samples from Tuxtepec (TUX1 \& TUX2), one sample, from Chiltepec (CHIL), four samples from Benemérito Juárez (BJ1, BJ2, BJ3, \& BJ4) and four samples from Loma Bonita (LB1, LB2, LB3, \& LB4). The samples were obtained directly from the producers with a period of no more of one day of storage prior to collection. The temperature of the sampling places varied between $36-40^{\circ} \mathrm{C}$. The sampling of the fresh cheese was carried out by the method indicated in the NMX-F-718-COFOCALEC-2006 (DOF, 2006). The samples were stored at $4^{\circ} \mathrm{C}$ and transported to the laboratory for analysis the next day in the Faculty of Zootechnics and Ecology at the Autonomous University of Chihuahua. The samples from both seasons were treated with the same protocols and all the analysis were performed by duplicate.

\subsection{Microbial counts and selective media}

A suspension of $10 \mathrm{~g}$ of cheese in $90 \mathrm{~mL}$ of phosphate buffer solution was homogenized for two minutes in a blender (Laboratory Blender, UK). The homogenate was left to rest for one minute to settle down the large particles. Then, $1 \mathrm{~mL}$ of the supernatant was used to perform serial decimal dilutions for plating in selective media for microbial counts.

Different selective media and growth conditions such as temperature and incubation time for counting the microorganisms by agar plates such as: Plate count agar (PCA; Oxoid), M17 agar (Oxoid) lactose (M17L), De Man, Rogosa, and Sharpe agar (MRS agar) MRSV, Baird Parker Agar (BPA; BD Bioxon), azide agar (KAA; Oxoid), Potato Dextrose Agar (PDA; BD Bioxon), and Violet Red Bile Lactose Agar (VRBLA; Oxoid). Colony-forming units (CFU) were determined by surface seeding with $100 \mu \mathrm{L}$ of the respective dilution. Only the VRBLA plates were inoculated with $1000 \mu \mathrm{L}$ per mass seeding.

The plates were incubated for 24-48 $\mathrm{h}$, at a temperature appropriated for the microorganisms. All the media were done in duplicate and incubated under anaerobic conditions except BPA, PCA, PDA, and VRBLA.

\subsection{Microbial identification}

\subsubsection{DNA extraction.}

The DNA extraction from the pellet was carried out according to the specifications of the Macherey-Nagel Nucleospin Tissue extraction kit with a single modification. Briefly, an aliquot of $1 \mathrm{~mL}$ of sample thawed at room temperature, was transferred in a new sterile tube of $1.5 \mathrm{~mL}$. The sample was centrifuged at $5000 \mathrm{rpm}$ for $5 \mathrm{~min}$ to obtain the pellet of 
microorganisms and the kit extraction was applied. To enhance the enzyme hydrolysis, a second addition a new pre-lysis solution containing $20 \mathrm{mM}$ Tris- $\mathrm{HCl} ; 2 \mathrm{Mm}$ EDTA; $1 \%$ Triton X-100 pH 8 and $2 \mathrm{mg} / \mathrm{ml}$ of lysozyme was performed.

\subsubsection{PCR amplification of $16 \mathrm{~s}$ rRNA}

Amplification of genomic DNA was performed according to the method reported elsewhere (Godálová et al., 2016). The temperature program consisted of initial denaturation at $94^{\circ} \mathrm{C}$ for $2 \mathrm{~min}, 40$ cycles $\left(94^{\circ} \mathrm{C}\right.$ for $1 \mathrm{~min}, 54^{\circ} \mathrm{C}$ for $1 \mathrm{~min}, 72{ }^{\circ} \mathrm{C}$ for 1 min) and a final polymerization step at $72^{\circ} \mathrm{C}$ for $5 \mathrm{~min}$, all amplifications being carried out in a Corbett Thermocycler (Corbett Research, Australia). The oligonucleotides used to amplify a 16S rRNA fragment present in the bacteria were those designed by Godálová et al., (2016). Analysis of the 16s region was performed and it was determined that the oligonucleotides span from region $\mathrm{V} 1$ to $\mathrm{V} 3$ and more specifically it amplifies the $\mathrm{V} 3$ region and only $10 \mathrm{bp}$ of the $\mathrm{V} 4$ region.

All the amplification reactions for PCR-DGGE were carried out in a final volume of $50 \mu \mathrm{L}$ with $200 \mathrm{ng}$ of DNA. GoTaq Green Master Mix (Promega Corp.), and $100 \mathrm{ng}$ of each oligonucleotide B = GplusR (5'-CGT CCT TCA TCG GCT - 3') and F = G17-CG (5'CGC CCG GGG CGC GCC CCG GGC GGG GCG GGG GCA CGG GGG GGT GAA GTC GTA ACA AGG - 3') were used for the amplification of the 16S rRNA gene. Reactions were carried out in a Corbett thermocycler under the following parameters: initial denaturation at $94^{\circ} \mathrm{C}$ for 2 min, followed by 30 cycles, each denaturing cycle at $93^{\circ} \mathrm{C}$ for 30 seconds and alignment at $78^{\circ} \mathrm{C}$ for 30 seconds and an extension at $72^{\circ} \mathrm{C}$ for 30 seconds, ending with a final extension of $72^{\circ} \mathrm{C}$ for $2 \mathrm{~min}$.

\subsubsection{Denaturing gradient gel electrophoresis (DGGE)}

DGGE was performed using a D-Code Universal Mutation Detection System (Bio-Rad, Richmond, Calif.) on $16 \mathrm{~cm} \times 16 \mathrm{~cm} \times 1 \mathrm{~mm}$ gels, following the method reported by Walter et al., 2000. From the banding profiles of the DGGE gels, the elution method used for the DNA fragments was done according to the technique proposed by Karnati et al., (2009). Once completing the PCR process, a 1.5\% agarose gel electrophoresis was run, then the amplicons underwent a sequencing process.

Wizard ${ }^{\circledR}$ SV Gel and PCR Clean-Up System kit (Promega Corporation) was the cleaner solution for the PCR products and in accordance with the specifications of the supplier (Jiang et al., 2011).

\subsubsection{Cutting, purification, and sequencing of DGGE products}

The amplicons embedded within the matrix of the agarose gel were cut directly from the gel under UV light and placed in a $1.5 \mathrm{~mL}$ microtube with $110 \mu \mathrm{L}$ of membrane binding solution added, and incubated at $65^{\circ} \mathrm{C}$ until the complete dissolution of the gel. Thereafter, the solution was placed inside the column and followed by the next steps: A 
volume of $25 \mu \mathrm{L}$ of membrane binding solution was added to the PCR reaction product and then gently mixed.

The total solution was transferred inside a minicolumn previously mounted in a $1.5 \mathrm{~mL}$ microtube, incubated for $1 \mathrm{~min}$ at room temperature, and then centrifuged at 13,000 rpm for $1 \mathrm{~min}$. The supernatant was discharged from the microtube and refilled with $700 \mu \mathrm{L}$ of membrane wash solution, then centrifuged again at $13000 \mathrm{rpm}$ for $1 \mathrm{~min}$. The washing process and centrifugation process were repeated but the volume of washing solution was only $500 \mu \mathrm{L}$ and the centrifugation time was 5 min. The supernatant was then discharged and refilled with $50 \mu \mathrm{L}$ of nuclease-free water, transferred into a new column, and incubated for $1 \mathrm{~min}$, then centrifuged at 13,000 rpm for 1 min to obtain a clean DNA eluate. DNA yield and purity parameters were obtained by using the NanoDrop kit (Thermo Scientific) and stored at $-20^{\circ} \mathrm{C}$ for later use.

From the purified products, $15 \mu \mathrm{L}$ was sent for automatic sequencing in the ABI PRISM ${ }^{\circledast}$ 3100 Genetic Analyzer kit (Perkin Elmer) to the Molecular Diagnostic and Analysis Unit of the National Institute of Public Health located at Cuernavaca city, Morelos, Mexico.

\subsection{Statistical analysis}

An analysis of variance (ANOVA) and a post-Tukey test described the data to contrast the seasons (summer and winter) count of the samples collected. A linear model with two explanatory factors of fixed effects at a level of $\alpha=0.05$, with the statistical program SAS/STAT® (SAS Institute Inc., 2004, version 9.0).

\section{RESULTS}

\subsection{Microbiologic analysis}

Firstly, it is important to declare that this work does not pretend to influence or interact with the owners and their processes. We agreed only to receive the samples and we cannot comment about the processes used to produce the cheeses. The cheese producers clearly explained that all materials that come into contact with the processing milk are cleaned to the best standards. They further iterated that until now, they have not received any complaints regarding cheese contamination by bacterial infection.

Microbiological analysis of artisan fresh cheese collected from eleven different producers in two seasons (summer and winter) based on specific culture media is reported in Table 1 as $\log _{10} \mathrm{CFU} / \mathrm{mL}$ (CFU to abbreviate).

The samples from BJ2 and LB2 showed less cell count concerning Enterococcus since they have an average from $4.58 \pm 0.15$ to $6.16 \pm 0.16$ CFU for summer and winter, respectively. The other samples maintained an average from 6.51 to $7.88 \mathrm{CFU}$ for both seasons. Regarding Lactobacillus mesophilic, the samples from LB1 and LB2 have less cell count of microorganisms, with a mean of 5.45 to 6.57 CFU. The samples obtained 
from CHIL had a wider variety of strains with a mean of 8.62 to $9.16 \mathrm{CFU}$ for both seasons. The mean in CFU for Leuconostoc, in the samples from LB3, was the less diverse for this group of bacteria. with an average of 4.62 CFU in winter, and there was no count of microorganisms in summer. This effect was due to the Leuconostoc species growth better in media containing sucrose, like in sugar cane juice, to produce dextrans. It is reported that Leuconostoc does not grow in temperatures higher than $40^{\circ} \mathrm{C}$ (Vos et al., 2011). In summer, the temperature in the Papaloapan region exceeds $45^{\circ} \mathrm{C}$. Samples from CHIL showed a greater cell count for this group, with an average of 7.78 to $8.02 \mathrm{CFU}$. The statistical analysis showed that samples from different producers collected in summer and winter were not significantly different ( $p>0.05)$ regarding the CFU count.

LB1 and LB2 samples showed less cell count concerning Streptococcus mesophilic, with a mean of 6.64 to $7.38 \mathrm{CFU}$, while the others maintained an average of 7.41 to 9.43 CFU for the two seasons. Regarding Streptococcus thermophiles (Table 1), the samples from LB2 have less cell count, with an average of 5.19 to $5.36 \mathrm{CFU}$, while the others maintained an average of 7.25 to $8.89 \mathrm{CFU}$ for the two seasons. The mean in CFU for mesophilic from LB1 and LB2 samples were the least count for this group of bacteria, with an average of 6.66 to $7.43 \mathrm{CFU}$, while for the other samples, an average from 7.54 to 9.73 CFU for both seasons was obtained. Lactococcus count in samples from LB1 and LB2 contained the lowest count, with a mean of 6.54 to 7.69 CFU. The samples from CHIL and BJ1 showed the highest count with a mean of 8.86 to $9.56 \mathrm{CFU}$ for the two seasons. The LB2 samples showed the lowest count of $S$. aureus, with an average of $5.71 \mathrm{CFU}$ in summer and $6.06 \mathrm{CFU}$ in winter. The remaining values for the other samples showed higher means from 6.48 to 8.93 CFU for both seasons. LB2 and BJ2 samples showed the lowest count of microorganisms, with an average of 4.85 to 6.72 CFU. The rest of the samples showed similar means of 6.43 to $8.67 \mathrm{CFU}$ for both seasons.

Analysis of molds and yeasts of samples from TUX1, TUX2, BJ1, BJ4, LB1, LB3, and LB4 show mold counts with averages from 3 to $3.8 \mathrm{CFU}$ in both seasons. The rest of the samples (CHIL, BJ2, BJ3, and LB2) were almost free of these kinds of microorganisms. The samples from LB3 were the only ones that did not show yeasts in the summer. The other sample showed a mean of 3.53 to 5.07 CFU in both seasons.

Results showed that all the samples collected in the Papaloapan region are in the permissible range for $\mathrm{LAB}$, as established by the Official Mexican Standard NOM-243SSA1-2010. However, the results of total coliforms, $S$. aureus, as well as molds and yeasts, were above the limits allowed in the standard (2, 3, and 2.69 CFU, respectively). $S$. aureus was one of the microorganisms most present in microbial count in all cheese samples, the presence of this microorganism is due to contamination of the material and work equipment or the milk as raw material. Contamination by $S$. aureus could also be infected by the workers (from the skin, mouth, and nostrils) during the process management and final product. The results suggested that there could be staphylococcal enterotoxins capable of causing poisoning to the consumer. 
Table 1. Microbial load found in samples of artisan fresh cheese from the Papaloapan Basin Region ( $\log _{10} \mathrm{CFU} / \mathrm{mL}$ ).

\begin{tabular}{|c|c|c|c|c|c|c|c|c|c|c|c|c|}
\hline cro & ason & UX 1 & TUX 2 & CHIL & BJ1 & BJ2 & BJ3 & BJ4 & LB1 & LB2 & LB3 & LB4 \\
\hline \multirow{2}{*}{$\begin{array}{l}\text { S. aureus } \\
\text { (1000 UFC/g) }\end{array}$} & $\mathrm{S}^{\mathrm{a}}$ & $3 \pm 0.02$ & 2 & 5 & $0.01 \pm$ & $6.86 \pm$ & 07 & $7.78 \pm 0.03$ & $6.58 \pm 0.03$ & $5.71 \pm 0.02$ & $.50 \pm 0.10$ & \pm 0.06 \\
\hline & v & $7.84 \pm 0.03$ & $8.40 \pm 0.11$ & $8.85 \pm 0.07$ & $8.78 \pm 0.06$ & $6.97 \pm 0.02$ & $7.89 \pm 0.07$ & $7.69 \pm 0.01$ & $6.48 \pm 0.05$ & $.06 \pm 0.8$ & $8.50 \pm 0.06$ & $7.80 \pm 0.03$ \\
\hline \multirow{2}{*}{$\begin{array}{l}\text { Enterococcus } \\
\text { (<100 UFC/g) }\end{array}$} & $S$ & $7.39 \pm 0.02$ & $7.59 \pm 0.03$ & $7.52 \pm 0.06$ & $7.75 \pm 0.08$ & $5.03 \pm 0.05$ & $7.70 \pm 0.06$ & $6.89 \pm 0.19$ & $6.64 \pm 0.02$ & $4.58 \pm 0.15$ & $7.65 \pm 0.05$ & $6.89 \pm 0.01$ \\
\hline & W & $7.36 \pm 0.01$ & $7.41 \pm 0.12$ & $7.56 \pm 0.06$ & $7.69 \pm 0.04$ & $6.03 \pm 0.11$ & $7.75 \pm 0.04$ & $7.88 \pm 0.07$ & $6.51 \pm 0.01$ & $6.16 \pm 0.16$ & $7.50 \pm 0.01$ & $6.72 \pm 0.02$ \\
\hline \multirow{2}{*}{$\begin{array}{l}\text { Total Coliforms } \\
(<100 \text { UFC/g })\end{array}$} & $S$ & $7.33 \pm 0.05$ & $7.88 \pm 0.09$ & $7.19 \pm 0.69$ & $8.67 \pm 0.16$ & $5.58 \pm 0.01$ & $8.35 \pm 0.04$ & $7.79 \pm 0.02$ & $6.97 \pm 0.04$ & $4.85 \pm 0.09$ & $8.13 \pm 0.05$ & $46 \pm 0.05$ \\
\hline & W & $7.26 \pm 0.05$ & $7.73 \pm 0.11$ & $7.61 \pm 0.05$ & $8.65 \pm 0.00$ & $6.72 \pm 0.02$ & $8.63 \pm 0.01$ & $7.69 \pm 0.10$ & $6.43 \pm 0.13$ & $5.73 \pm 0.06$ & $7.88 \pm 0.07$ & $7.56 \pm 0.06$ \\
\hline \multirow{2}{*}{$\begin{array}{l}\text { Lactobacillus } \\
\text { mesophiles }\end{array}$} & $S$ & $7.57 \pm 0.16$ & $8.65 \pm 0.3$ & $9.16 \pm 0.22$ & $8.62 \pm 0.02$ & $7.61 \pm 0.05$ & $7.67 \pm 0.08$ & $7.09 \pm 0.26$ & $6.57 \pm 0.01$ & $5.45 \pm 0.10$ & $8.22 \pm$ & $7.61 \pm$ \\
\hline & W & 7.4 & $8.42 \pm 0.09$ & $8.62 \pm 0.04$ & $8.62 \pm 0.09$ & $7.52 \pm 0.09$ & $7.60 \pm 0.01$ & $7.27 \pm 0.3$ & $6.30 \pm 0.03$ & $5.61 \pm 0.06$ & $8.27 \pm 0.06$ & \\
\hline \multirow{2}{*}{ Leuconostoc } & $S$ & $5.59 \pm 0.03$ & $7.34 \pm 0.09$ & $8.02 \pm 0.02$ & $6.52 \pm 0.08$ & $5.32 \pm 0.07$ & $6.79 \pm 0.12$ & $5.61 \pm 0.5$ & $4.95 \pm 0.06$ & $5.09 \pm 0.02$ & $0.00 \pm 0.00$ & $5.64 \pm 0.05$ \\
\hline & W & $5.43 \pm 0.10$ & $7.28 \pm 0.04$ & $7.78 \pm 0.02$ & $5.16 \pm 0.12$ & $5.17 \pm 0.14$ & $6.24 \pm 0.10$ & $5.37 \pm 0.03$ & $4.92 \pm 0.03$ & $5.03 \pm 0.11$ & $4.62 \pm 0.21$ & $5.22 \pm 0.07$ \\
\hline \multirow{2}{*}{$\begin{array}{l}\text { Enterococcus } \\
\text { mesophiles }\end{array}$} & $S$ & $7.80 \pm 0.07$ & $8.85 \pm 0.00$ & $9.07 \pm 0.00$ & $8.67 \pm 0.17$ & $7.41 \pm 0.22$ & $8.60 \pm 0.03$ & $8.29 \pm 0.16$ & $6.75 \pm 0.3$ & $6.80 \pm 0.01$ & $8.43 \pm 0.04$ & $7.74 \pm 0.06$ \\
\hline & W & $7.88 \pm 0.01$ & $8.77 \pm 0.04$ & $9.01 \pm 0.02$ & $8.67 \pm 0.07$ & $7.55 \pm 0.07$ & $8.46 \pm 0.03$ & $8.42 \pm 0.14$ & $7.38 \pm 0.3$ & $6.64 \pm 0.11$ & $9.43 \pm 0.07$ & $8.58 \pm 0.02$ \\
\hline \multirow{2}{*}{$\begin{array}{l}\text { Streptococcus } \\
\text { thermophilus }\end{array}$} & $S$ & $7.53 \pm 0.25$ & $8.00 \pm 0.05$ & $8.89 \pm 0.03$ & $8.36 \pm 0.30$ & $7.25 \pm 0.03$ & $7.87 \pm 0.07$ & $7.40 \pm 0.11$ & $6.82 \pm 0.05$ & $5.36 \pm 0.05$ & $7.40 \pm 0.11$ & $7.78 \pm 0.03$ \\
\hline & W & $7.72 \pm 0.14$ & $7.98 \pm 0.05$ & $8.46 \pm 0.03$ & $8.51 \pm 0.10$ & $7.82 \pm 0.10$ & $7.67 \pm 0.02$ & $7.63 \pm 0.13$ & $6.77 \pm 0.06$ & $5.19 \pm 0.11$ & $7.32 \pm 0.05$ & $7.37 \pm 0.10$ \\
\hline \multirow{2}{*}{$\begin{array}{l}\text { Fungi } \\
\text { ( } 500 \text { UFC/g) }\end{array}$} & $S$ & $3.53 \pm 0.8$ & $3.50 \pm 0.28$ & $0.00 \pm 0.00$ & $3.38 \pm 0.55$ & $0.00 \pm 0.0$ & $0.00 \pm 0.0$ & $3.53 \pm 0.8$ & $3.38 \pm 0.12$ & $0.00 \pm 0.00$ & $0.00 \pm 0.00$ & $0.00 \pm 0.00$ \\
\hline & W & $0.00 \pm 0.00$ & $3.00 \pm 0.00$ & $0.00 \pm 0.04$ & $3.38 \pm 0.12$ & $0.00 \pm 0.0$ & $0.00 \pm 0.0$ & $0.00 \pm 0.00$ & $0.00 \pm 0.0$ & $0.00 \pm 0.00$ & $0.00 \pm 0.00$ & $3.00 \pm 0.00$ \\
\hline \multirow{2}{*}{$\begin{array}{l}\text { Yeast } \\
(500 \text { UFC/g) }\end{array}$} & $S$ & $4.79 \pm 0.01$ & $4.46 \pm 0.06$ & $4.77 \pm 0.04$ & $4.22 \pm 0.7$ & $3.97 \pm 0.9$ & $5.07 \pm 0.1$ & $4.66 \pm 0.01$ & $4.44 \pm 0.12$ & $4.77 \pm 0.08$ & $0.00 \pm 0.00$ & $4.61 \pm 0.08$ \\
\hline & W & $4.35 \pm 0.04$ & $4.21 \pm 0.14$ & $4.39 \pm 0.16$ & $4.07 \pm 0.17$ & $3.80 \pm 0.14$ & $4.50 \pm 0.6$ & $3.99 \pm 0.12$ & $4.06 \pm 0.02$ & $4.36 \pm 0.19$ & $3.53 \pm 0.08$ & $4.22 \pm 0.07$ \\
\hline \multirow{2}{*}{$\begin{array}{l}\text { Mesophiles } \\
(200,000 \text { UFC/g) }\end{array}$} & $S$ & $7.82 \pm 0.03$ & $8.54 \pm 0.03$ & $8.91 \pm 0.02$ & $8.80 \pm 0.04$ & $8.42 \pm 0.09$ & $8.65 \pm 0.04$ & $7.54 \pm 0.05$ & $6.75 \pm 0.24$ & $6.87 \pm 0.24$ & $8.48 \pm 0.05$ & $7.67 \pm 0.09$ \\
\hline & W & $7.68 \pm 0.08$ & $8.75 \pm 0.09$ & $9.46 \pm 0.06$ & $9.73 \pm 0.07$ & $8.74 \pm 0.01$ & $8.65 \pm 0.10$ & $7.57 \pm 0.17$ & $6.66 \pm 0.17$ & $7.43 \pm 0.16$ & $8.61 \pm 0.01$ & $7.84 \pm 0.01$ \\
\hline \multirow{2}{*}{ Lactococcus } & $S$ & $7.81 \pm 0.02$ & $8.80 \pm 0.02$ & $9.21 \pm 0.02$ & $8.86 \pm 0.09$ & $7.59 \pm 0.01$ & $7.96 \pm 0.01$ & $7.84 \pm 0.01$ & $6.59 \pm 0.01$ & $6.54 \pm 0.05$ & $8.19 \pm 0.04$ & $7.90 \pm 0.03$ \\
\hline & W & $8.01 \pm 0.03$ & $8.92 \pm 0.09$ & $9.48 \pm 0.07$ & $9.56 \pm 0.03$ & $7.74 \pm 0.01$ & $8.75 \pm 0.05$ & $7.53 \pm 0.04$ & $6.71 \pm 0.01$ & $7.69 \pm 0.02$ & $8.56 \pm 0.04$ & $8.47 \pm 0.08$ \\
\hline
\end{tabular}

Note: $S^{\mathrm{a}}$ : Summer, $\mathrm{W}^{\mathrm{b}}$ : Winter. Results are the average and Std. Dev of two replicates. 


\subsection{Genetic Identification of microbiota}

\subsubsection{Microbiota Analysis in summer}

Cheese samples were collected on the same day of the summer of 2014. The temperature for sampling places varied between 36-40 ${ }^{\circ} \mathrm{C}$. The DNA extracted from the 11 samples of fresh cheese collected underwent further processing. Fig. 1 shows the amplification performed by the PCR technique using the GoTaq ${ }^{\circledR}$ Green Master Mix (Promega), thus achieving an amplification of approximately $450 \mathrm{bp}$, observing nonspecific fragments, using the oligos $B=G+R$ and $G 17$. PCR was performed with oligonucleotides $F=G 17-C G$ and $B=G+R$ for DGGE.

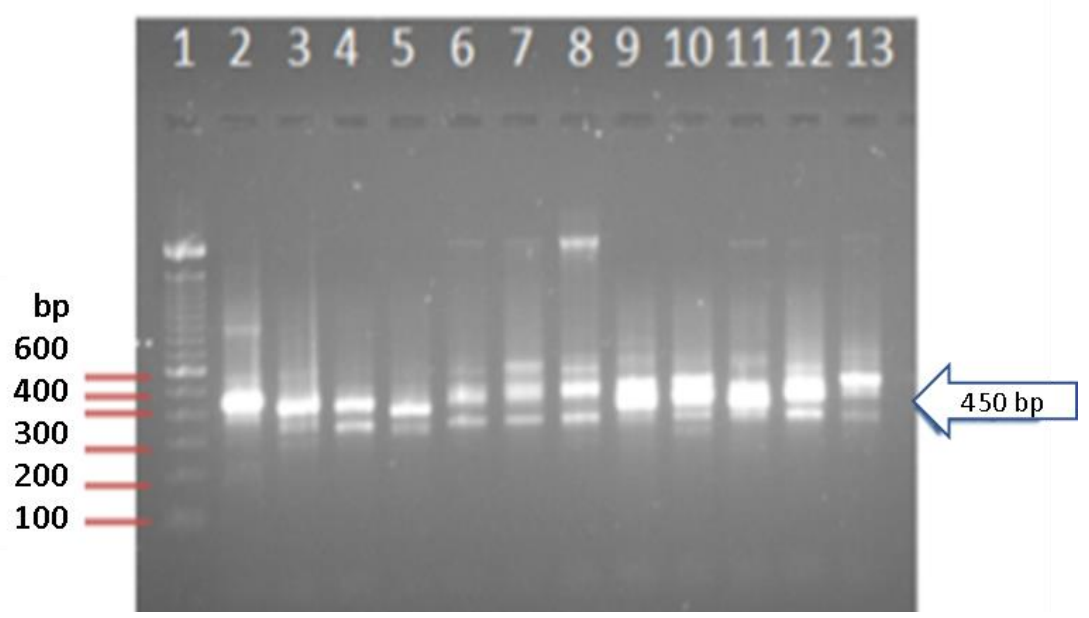

Fig. 1. 16S rRNA amplification gene. Gel electrophoresis (1.5\% agarose) stained with ethidium bromide from amplicons of fresh cheese samples from the summer season. 1) Molecular weight marker $1000 \mathrm{bp} 1.5 \mu \mathrm{l}(100 \mathrm{ng} / \mu \mathrm{L})$. 2) Positive control. 3) TUX1. 4) TUX2. 5) CHIL. 6) LB1. 7) LB2. 8) LB3. 9) LB4. 10) BJ1. 11) BJ2. 12) BJ3. 13) BJ4. A volume of $10 \mu \mathrm{L}$ of each sample was added into different wells. Image analyzed with ImageJ.

Fig. 2 shows the banding profile of the bacterial populations. Subsequently, the PCRDGGE gel was analyzed and bands of interest were chosen based on the intensity of the banding or the presence of some bands only in some samples. Each band represents a bacterial species. Subsequently, the profile of each community was associated with groups by calculating a matrix of Euclidean distances with the help of BioNumerics software (version 6.6; Applied Math, Austin Tx) and using the UPGMA technique. The DNA contained in the selected bands were re-amplified with the same nucleotide pair from the selected bands, the numbers 15, 17, 18, 21, 22, 23, and 26 were not sequenced as the concentration and purity were not adequate for their sequencing. For each sequence obtained, the forward and reverse products were assembled, obtaining the consensus sequences for a total of 19 samples managed. 


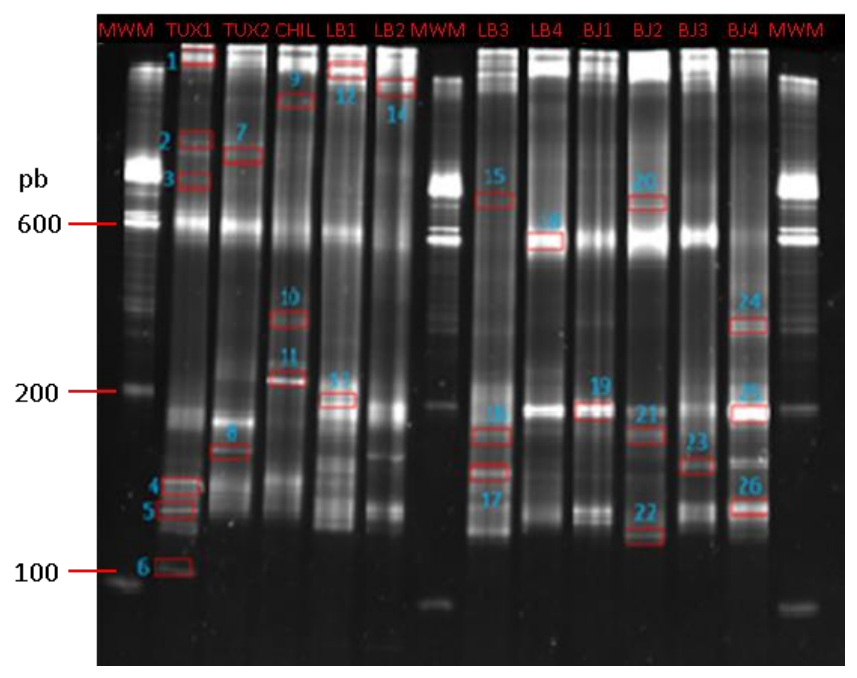

Fig. 2. Banding profile of bacterial populations. Selected bands are identified with numbers in blue color.

Fig. 3 shows the dendrogram obtained by calculating Euclidean distances. The clusters obtained are the results of the difference in sampling place and preparation mode. The percentage of similarities are shown in the formed nodes. The results showed that the profiles originating from the samples collected in Tuxtepec (TUX1 \& TUX2) were the most similar, forming a group with $66.7 \%$ similarity. This result suggests that cell count is affected by the origin and the method of preparation of the cheeses. The other samples were more related to each other, groups of $50.9 \%$ similarity, where groups and subgroups were formed. Besides, they were different from the first group with $43.2 \%$ similarity. For the rest of the samples, the place of origin and mode of preparation did not influence their bacterial cell count.

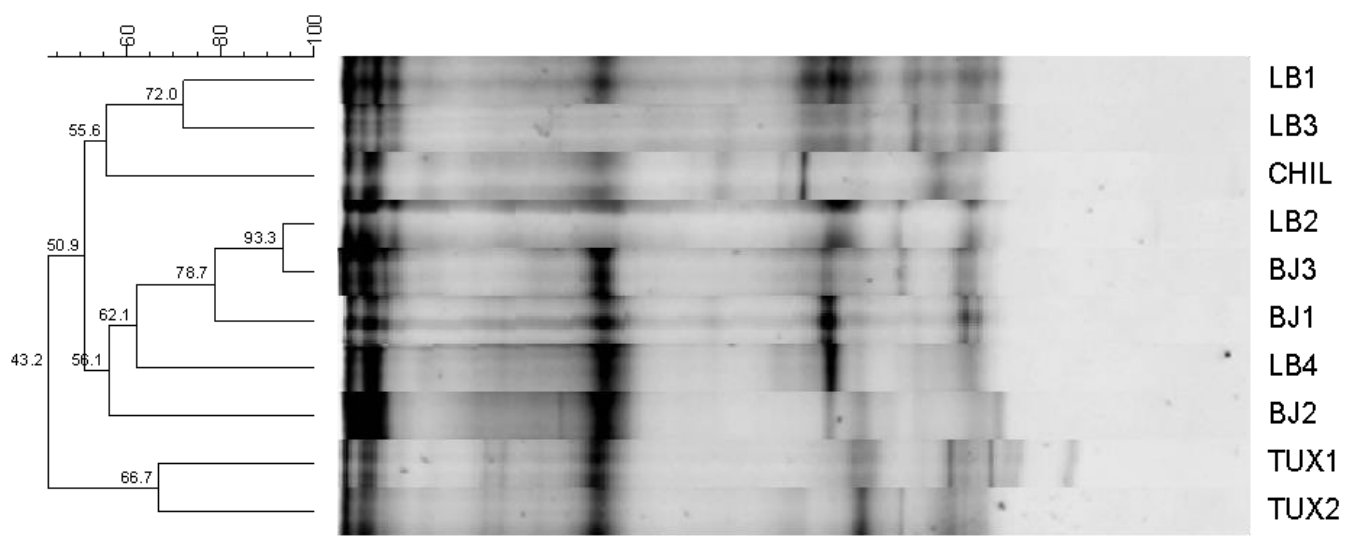

Fig. 3. UPGMA dendrogram showing the genetic relationships among the communities. PCR-DGGE of the bacterial communities present in fresh artisan cheeses collected in summer. 
According to the database from GenBank, the most common microorganisms found in these fresh artisan cheeses were Streptococcus, Lactococcus, Leuconostoc, Lactobacillus, Enterococcus, Pediococcus, Deinococcus, and Enterobacter. Other microorganisms found were Halobacteroides, Holoterrigena, and Salmonella (Table 2).

The original sequences, without making any changes, were analyzed using Sequencer 5.3 (Gene Codes Corp., Ann Arbor, Ml) and compared to the sequences available from GenBank using the BLASTN program at NCBI (National Center for Biotechnology Information). Fig. 4 shows the bacteria found in the samples and analyzed according to the results shown in the gel of the DGGE products. The analyses show the variety of microorganisms of the sample from different geographical areas in the Papaloapan region.

Table 2. Reference markers obtained from the GenBank database

\begin{tabular}{|c|c|c|c|}
\hline $\begin{array}{l}\text { DGGE } \\
\text { band }\end{array}$ & Taxonomic identification* & $\begin{array}{c}\text { Similarity } \\
(\%)\end{array}$ & $\begin{array}{l}\text { Access } \\
\text { Number }\end{array}$ \\
\hline 1 & $\begin{array}{l}\text { Haloterrigena saccharevitans strain JCM } \\
12889\end{array}$ & 100 & NR_113512.1 \\
\hline 2 & Pediococcus lolii strain NGRI 0510Q & 99 & NR_041640.1 \\
\hline 3 & Halobacteroides halobius strain DSM 5150 & 99 & $N R^{-} 102480.1$ \\
\hline 4 & Deinococcus peraridilitoris strain DSM 19664 & 92 & $N R^{-} 102475.1$ \\
\hline 5 & Pediococcus Iolii strain NGRI 0510Q & 99 & NR_041640.1 \\
\hline 6 & --- & -- & \\
\hline 7 & $\begin{array}{l}\text { Streptococcus oligofermentans strain AS } \\
1.3089\end{array}$ & 100 & NR_103943.1 \\
\hline 8 & Enterobacter aerogenes strain KCTC 2190 & 100 & NR_102493.1 \\
\hline 9 & Lactobacillus fermentum strain CIP 102980 & 96 & NR_-104927.1 \\
\hline 10 & $\begin{array}{l}\text { Streptococcus oligofermentans strain AS } \\
1.3089\end{array}$ & 100 & NR_194033.1 \\
\hline 11 & Pediococcus Iolii strain NGRI 0510Q & 100 & NR_041640.1 \\
\hline 12 & $\begin{array}{l}\text { Staphylococcus saprophyticus strain ATCC } \\
15305\end{array}$ & 94 & NR_074999.1 \\
\hline 13 & Enterococcus faecalis strain LMG 7937 & 91 & NR_114782.1 \\
\hline 14 & $\begin{array}{l}\text { Streptococcus oligofermentans strain AS } \\
1.3089\end{array}$ & 100 & NR_103943.1 \\
\hline 16 & Enterococcus hirae strain ATCC 9790 & 100 & NR_075022.1 \\
\hline 19 & $\begin{array}{l}\text { Salmonella enterica subsp. enterica serovar } \\
\text { Typhimurium strain LT2. }\end{array}$ & 100 & NR_074910.1 \\
\hline 20 & $\begin{array}{l}\text { Streptococcus saliviloxodontae strain NUM } \\
6306\end{array}$ & 100 & NR_126178.1 \\
\hline 24 & ALeuconostoc rapi strain LMG 27676 & 98 & NR_136799.1 \\
\hline 25 & ${ }^{\mathrm{A}}$ Lactococcus lactis subsp. tructae strain L105 & 82 & NR 116443.1 \\
\hline
\end{tabular}

Note: All the identification was done by the $16 \mathrm{~S}$ ribosomal RNA gene complete sequence, only bands 24 and 25 were obtained by partial sequence ${ }^{A}$ 
Lactococcus lactis was detected in band 13 in the sample LB1. LAB such as Streptococcus and Pediococcus were found in the samples, as previously reported by Stiles \& Holzapfel, (1997). The results show the presence of other genera in a lower percentage as Proteus, shimia, Rhizophydium, Pseudomonas, Halocella, Longilinea, Myxococcus, Nannocystis, Phormidium, Serratia, and Sorangium. Most of these genera are present because of the cheese handling and from raw milk, to the final product.

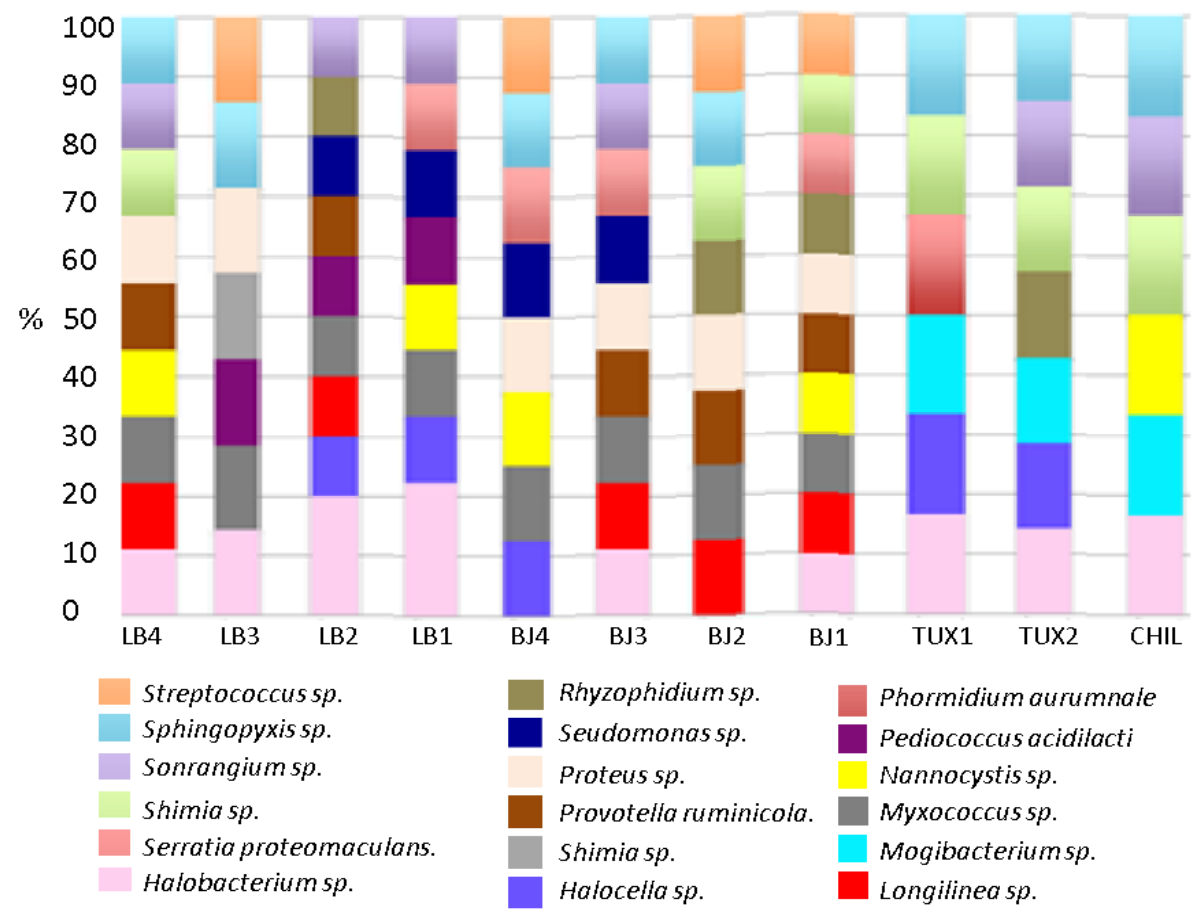

Fig. 4. Bacteria found in artisan fresh cheese samples in summer.

\subsubsection{Microbiota Analysis in the winter season.}

The samples were collected in January 2015 from the same places as the samples collected in summer, and treated with the same protocols. Thus, the aim was the same to identify the microbiota of the fresh artisan cheese in the winter season.

The banding profile of the bacterial populations from 11 artisan fresh cheeses, applying PCR technique as in summer samples and is illustrated in Supplemental Materials. The electrophoresis gel in 1.5\% agarose, stained with ethidium bromide from amplicons of fresh cheese samples from the winter season is reported in Fig. 5. The selected bands of better resolution are reported in Fig. 6, each band corresponds to a bacterial species. These data were the key to identify the microorganisms present in the artisan fresh cheese in the winter season. Fig. 7 shows the dendrogram obtained by calculating 
Euclidean distances. It is observed that the groups were the main source of variation, being the place of origin and method of preparation, indicated in the nodes formed, the percentage of similarities.

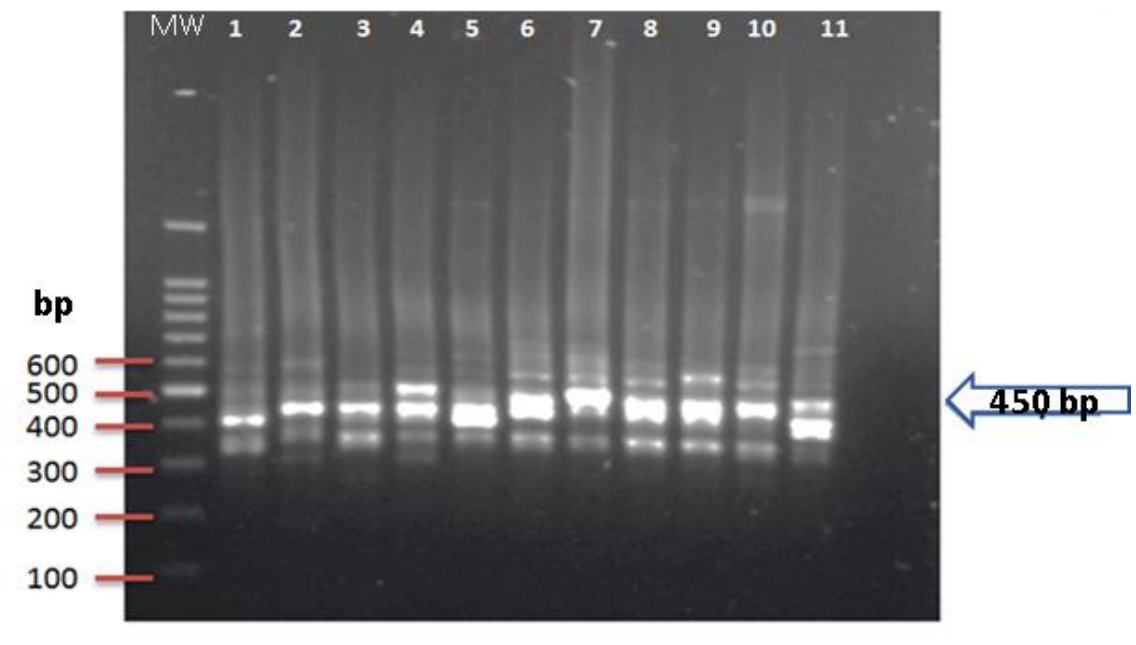

Fig. 5. Electrophoresis gel in agarose at 1.5\% made with the amplicons of the samples of fresh cheese from the winter season and stained with ethidium bromide. WP) Molecular weight marker 1000 bp $1.5 \mu \mathrm{L}$ (100 ng / $\mu \mathrm{L}$ ). 1) CHI $10 \mu \mathrm{L}$. 2) Tux1 $10 \mu \mathrm{L} .3$ ) Tux2 $10 \mu \mathrm{L}$. 4) BJ1 $10 \mu \mathrm{L}$. 5) BJ2 $10 \mu \mathrm{L}$. 6) BJ3 $10 \mu \mathrm{L}$. 7) BJ4 $10 \mu \mathrm{L} .8)$ LB1 $10 \mu \mathrm{L} .9$ ) LB2 $10 \mu \mathrm{L}$. 10) LB3 $10 \mu \mathrm{L}$. 11) LB4 $10 \mu \mathrm{L}$. Image analyzed with ImageJ.

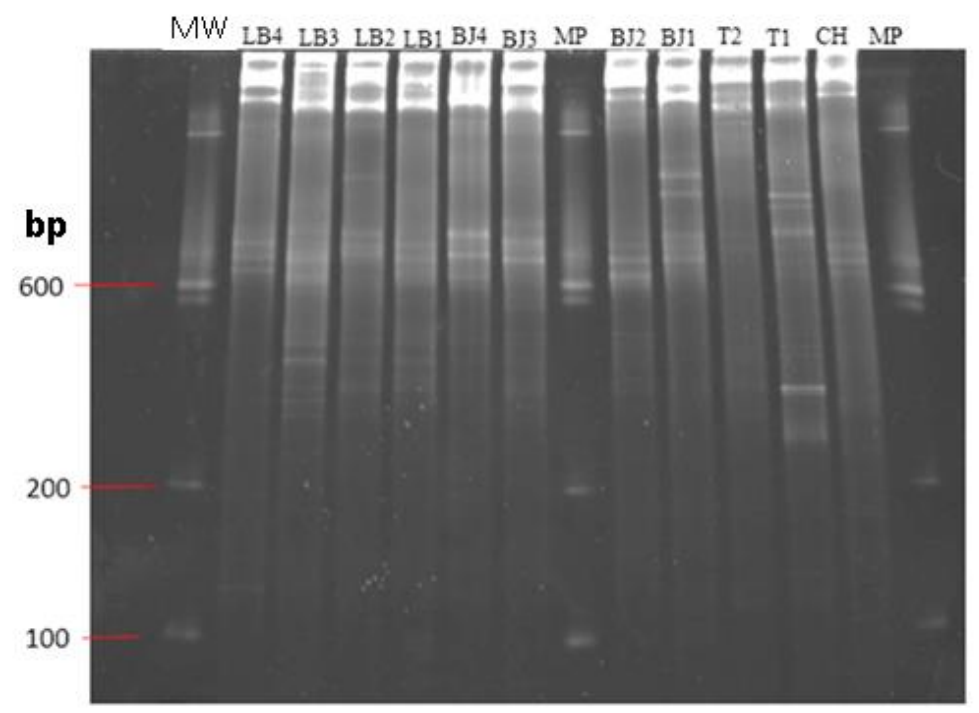

Fig. 6. Banding profile of bacterial populations. Each band represents a bacterial species. Running amplicons were obtained with DNA samples from fresh artisan cheeses collected in winter. 
The results show two groups, the profile originated from the TUX1 sample with a $40.8 \%$ similarity to the rest of the samples. For the other samples, they were more related to each other and with $57.1 \%$ of similarity, where groups and subgroups were formed. These results show that the samples, the place of origin, and the method of cheese preparation influence their bacterial cell count.

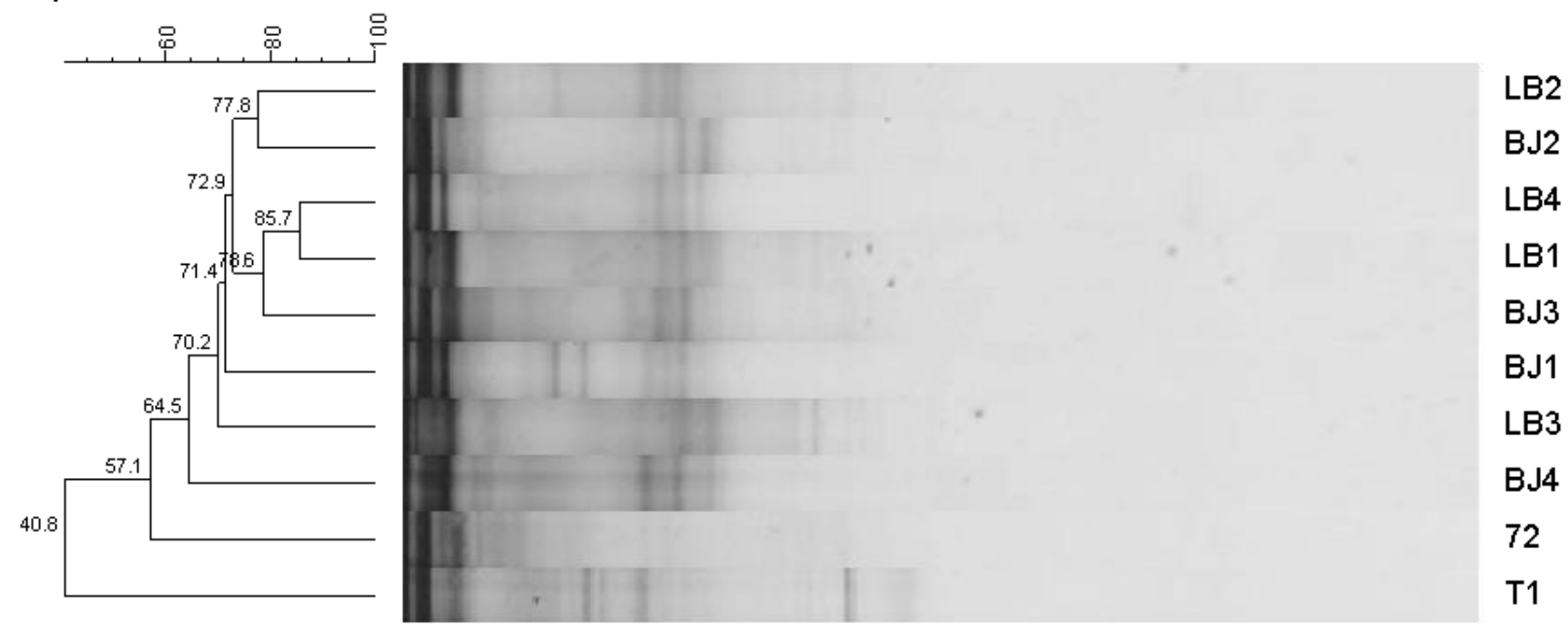

Fig. 7. UPGMA dendrogram showing the genetic relationships among the communities. PCR-DGGE of the bacterial communities present in fresh artisan cheeses collected in winter.

The PCR-DGGE gel was analyzed, and the bands of interest were chosen, based on the intensity of the banding or the presence of some bands only in some samples. The DNA contained in the selected bands is shown in Fig. 8. The products were re-amplified with the same nucleotide pairs. From the total selected bands, band numbers 1, 3, 8, 13, 16 , and 18 were not sequenced because the concentration and purity were not reached for their sequencing. In total, 11 bands were sequenced.

From the results found in the GenBank database (Table 3), a variety of microorganisms were identified, as follows: Lactococcus, Streptococcus, Lactococcus, Leuconostoc, Enterococcus, Pediococcus, Enterobacter, Klebsiella, Bacillus, Staphylococcus, and Salmonella. Lactococcus and Streptococcus were the most representative in the DGGE profile of the cheese samples. Lc. lactis subsp. Cremoris was the bacteria found at two sampling points and was the most widespread. In the results obtained from the products of the DGGE gel, the analysis showed the variety of microorganisms for each sample collected at different geographical points in the Papaloapan region. The predominant bacteria in all samples were Bacillus sp., with $30-50 \%$ of its concentration (Fig. 9). The presence of Bacillus $s p$. in cheese samples is related to the presence of multicopy copies of the 16S rRNA gene for these microorganisms (Cocolin et al., 2004, 2007; Dahllöf et al., 2000). 


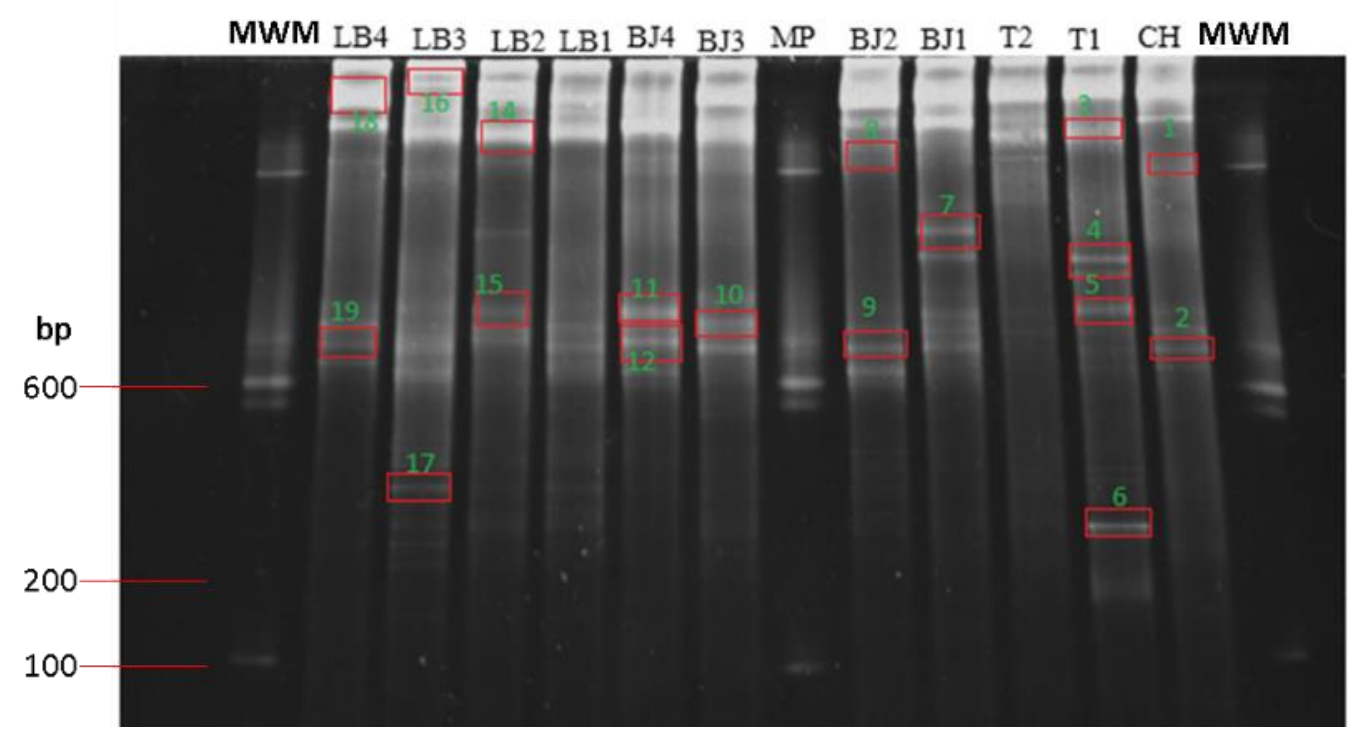

Fig. 8. Selected gel bands in DGGE seen with the aid of BioRad software. The running amplicons were obtained with samples of fresh artisan cheeses collected in winter.

Table 3. Reference markers obtained from the GenBank database for winter samples

\begin{tabular}{|c|c|c|c|}
\hline $\begin{array}{l}\text { DGGE } \\
\text { band }\end{array}$ & Taxonomic identification & $\begin{array}{c}\text { Similarity } \\
(\%)\end{array}$ & $\begin{array}{l}\text { Access } \\
\text { Number }\end{array}$ \\
\hline 2 & $\begin{array}{l}\text { Klebsiella quasipneumoniae subsp. } \\
\text { quasipneumoniae strain } 01 \mathrm{~A} 030 .\end{array}$ & 82 & NR_134062.1 \\
\hline 4 & Pediococcus Iolii strain NGRI 0510Q & 92 & NR_041640.1 \\
\hline 5 & Leuconostoc kimchii strain IMSNU 11154 & 93 & NR_075014.1 \\
\hline 6 & Streptococcus oligofermentans strain AS 1.3089 & 97 & $N R \_103943.1$ \\
\hline 7 & $\begin{array}{l}\text { Lactococcus lactis subsp. cremoris strain NBRC } \\
100676\end{array}$ & 82 & NR_113925.1 \\
\hline 9 & Enterobacter aerogenes strain KCTC 2190 & 100 & NR_102493.1 \\
\hline 10 & Enterococcus hirae strain ATCC 9790 & 100 & NR 075022.1 \\
\hline 11 & $\begin{array}{l}\text { Salmonella enterica subsp. enterica serovar } \\
\text { Typhimurium strain LT2 }\end{array}$ & 100 & NR_074910.1 \\
\hline 12 & $\begin{array}{l}\text { Lactococcus lactis subsp. cremoris strain NBRC } \\
100676\end{array}$ & 100 & NR_113925.1 \\
\hline 14 & Streptococcus oligofermentans strain AS 1.3089 & 92 & NR_103943.1 \\
\hline 15 & $\begin{array}{l}\text { A Staphylococcus pseudolugdunensis strain } \\
\text { B006 }\end{array}$ & 100 & NR_115938.1 \\
\hline 17 & $\begin{array}{l}\text { A Lactococcus lactis subsp. cremoris strain } \\
\text { NBRC } 100676\end{array}$ & 94 & NR_113925.1 \\
\hline 19 & Bacillus coagulans strain NBRC 12583 & 99 & NR_041523.1 \\
\hline
\end{tabular}




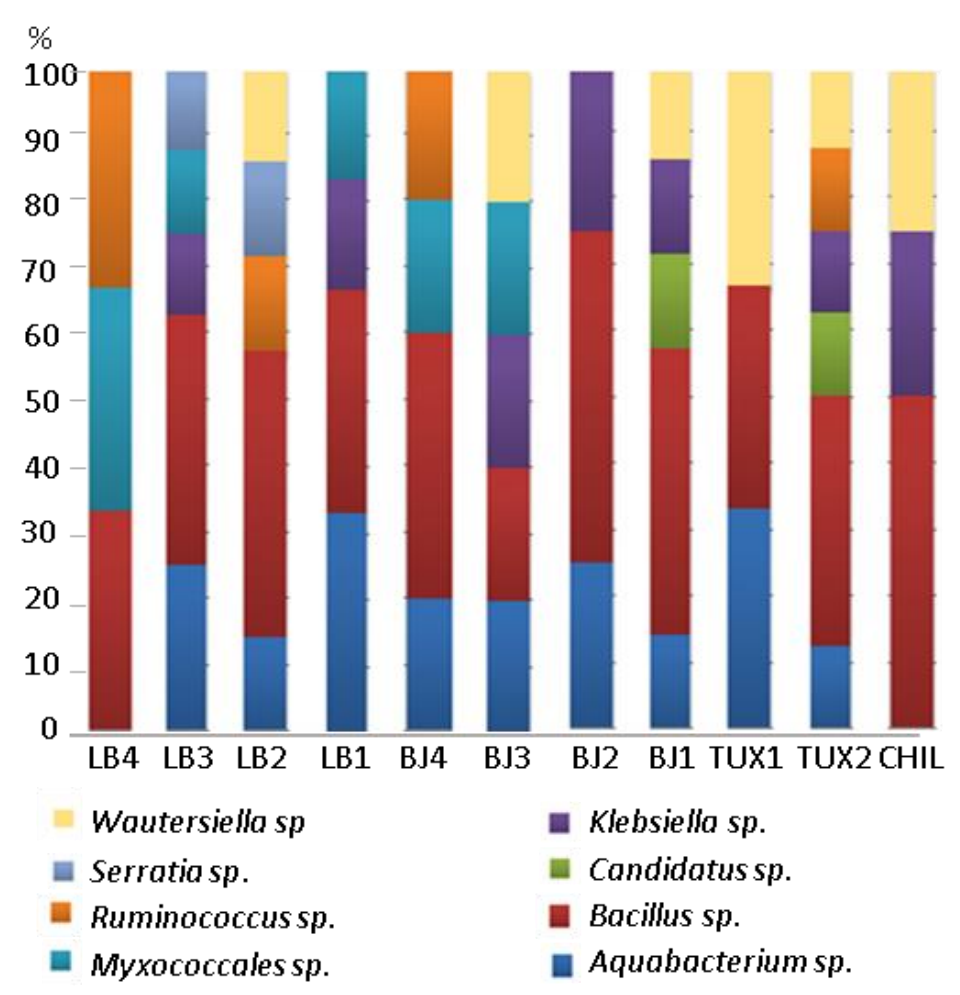

Fig. 9. Bacteria found in artisan fresh cheese samples in winter.

Aqueabacterium sp. was found in most of the samples, except LB4 and CHIL. This bacterium has been found in drinking water (Kalmbach, 1999). Klebsiella, Wautersiella, and Serratia were found in CHIL, TUX1, TUX2, BJ1, BJ2, BJ3, LB1, LB2, and LB3. These bacteria can infect the urinary or respiratory systems, including pneumonia (Podschun, and Ullmann, 1998). Candidatus sp. was found in the TUX2 and BJ1 samples at concentrations of $10 \%$. This bacterium could be well characterized because it is not easily cultivable (Murray, 1995). Ruminococcus sp. was found in sample LB4 at a concentration of $30 \%$ and in a lower concentration in samples LB2, LB4, and TUX2. Ruminococcus is a genus of bacteria in the class Clostridia, present in significant quantities in the intestines of humans (Liu et al., 2008). Myxococcales sp. presented in LB4, LB3, LB1, BJ4, and BJ3. This bacterium lives in sites rich in organic matter such as soil, manure, animal excrement, and plant wastes. Furthermore, they are capable of degrading polysaccharides, such as cellulose and chitin (Kiskowski et al., 2004).

\section{DISCUSSION}

All products for human consumption must have control of the microbial load to be consumed safely. Fermented products, such as cheeses, yogurts, canned vegetables, and even meat products, are more at risk of being contaminated by manual handling of 
the process and raw materials. In the case of fresh artisan cheeses, the situation is the same. According to Klaenhammer et al. (2002), the main genres of the BAL group present in cheese are Lactococcus, Lactobacillus, Leuconostoc, Enterococcus, and Streptococcus. Concordantly, our results also confirmed the presence of these kinds of microorganisms in samples of fresh artisan cheeses (Ruvalcaba-Gómez et al., 2020; Sánchez-Juanes et al., 2020; Yeluri Jonnala et al., 2018).

Some strains were found because of the processing of the raw milk, raw milk from the origin to produce the fresh cheeses. Halobacteria $s p$, predominance is because this strain grows in salty environments at temperatures of $42^{\circ} \mathrm{C}$ (DasSarma et al., 2006). Provotella ruminicola (TUX1, TUX2, and CHIL) is one of the bacteria that carry out the digestion of pectin through a fermentative process (Dehority, 1969). Pectin represents about 10 to $20 \%$ of the total carbohydrates that make up the forages used in ruminant nutrition. The presence of Mogibacterium sp (TUX1, TUX2, and CHIL) is associated with livestock feed and milk production. These bacteria are associated with moderate and severe oral diseases, found in oral cavities (including dental plaque), periodontal lesions, dental infections, and carious dentin (Holdeman et al., 1980; Nakazawa et al., 2000). Sphingopyxis (CHIL, TUX1, TUX2, BJ2, BJ3, BJ4, LB3, and LB4) is a ubiquitous bacterium in a variety of environments, such as salty water, compost, wastewater, and water contaminated with hexachlorocyclohexane. Sphingopyxis sp. is of industrial interest because this genus is capable of degrading mono and polycyclic aromatic hydrocarbon compounds (Kim et al., 2014).

Castro et al. (2016) isolated LAB from Minas, Brazil artisan cheese from the Campo das Vertentes region, regardless of the season. Enterococcus faecalis was isolated with higher frequency in samples of raw milk, endogenous starter culture, and fresh cheeses, followed by $L c$. lactis and $L b$. plantarum. Lb. paracasei, Lb. brevis, Enterococcus pseudoavium, and Aerococcus viridans.

In our study, Lc. lactis was present in the samples and it has an industrial interest since it produces the bacteriocin called Nisin. Nisin is currently the only bacteriocin approved by the FDA as a food preservative to inhibit the growth of pathogenic microorganisms (Fraga Cotelo et al., 2013; Klaenhammer, 1988). However, there are bacteriocins isolated from other genera of LAB such as Pediococcus acidilactici, Lb. plantarum, Lb. sake, Lb. plantarum, and Lb. helveticus (Castro-Castillo et al., 2013). Therefore, it is preferable to have a dominant $L A B$ because the production of bacteriocins could help to maintain a low level of the count of pathogen microorganisms.

Moreover, it is a common practice to use sodium chloride $(\mathrm{NaCl})$ during the production of artisan cheeses. The positive effect of $\mathrm{NaCl}$ is that it modifies the physical properties of the cheese curd and rind, controls the growth of the cheese-ripening microflora, and also limits the development of both pathogens and spoilage microbes. However, partial substitution of $\mathrm{NaCl}$ by other chloride salts such as potassium chloride represents an alternative option to limit the negative effects of reducing $\mathrm{NaCl}$ content in soft cheese. (Dugat-Bony et al., 2016). Synergistically, the production of bacteriocin contributes to 
stopping the proliferation of pathogens. LAB increase the shelf life of fresh cheese due to the production of these antimicrobial compounds. Evaluating the microbiological quality of the final fresh cheese product as well as the intermediates throughout the production line is an important contribution to control the quality of the product, as suggested for the production of mozzarella cheese (Losito et al., 2014). In other studies, dynamic populations isolated from whey, from artisan string cheeses manufactured with raw milk, have been reported in the literature (Martínez-López et al., 2016; Moser et al., 2018). Isolates of whey from artisan string cheese showed that Enterococcus and Lactobacillus were the dominant genera (Luiz et al., 2016). In another characterization, Oaxaca cheese showed a similar microbiota pattern. The microbiota of Oaxaca cheese had 43 strains of LAB, 38 coliforms, 24 yeasts, and 16 Staphylococcus. This microbiota represents high health risks for its consumption (Castro-Castillo et al., 2013). The same type of cheese called Aro cheese, marketed in the municipality of Teotitlán de Flores Magón, Oaxaca, Mex., showed similar microbial characteristics. The most representative microorganisms were: Aerobic mesophilic bacteria, psychrophilic bacteria, total coliforms, Escherichia coli, S. aureus, Salmonella, Enterococcus, Streptococcus, LAB, molds, and yeasts (González-Montiel \& Franco-Fernández, 2015) (González-Montiel \& Franco-Fernández, 2015). In another study, genera analysis showed that among three brands of Hispanic fresh cheese from the USA, the microbial community showed more similarity within the brands than when compared among them. Thermus Anoxybacillus, and Streptococcus accounted for the dominant genera of cheese brands (Holle et al., 2018). The literature shows that artisan cheeses have similar microbiota.

On the other hand, the pathogenic bacterium Salmonella enterica was present in the samples and was detected by the sequence analysis. Salmonella enterica is responsible for infections in humans and domestic animals (Porwollik et al., 2004). Salmonella can adapt to organic acids, particularly at pH 6.0 or pH 5.0. However, when the $\mathrm{pH}$ is lower ( $\mathrm{pH} 4.0$ ), bacterial survival is not viable after 6 to $24 \mathrm{~h}$ (Burin et al., 2014).

Fresh cheese is a very nutritious food and there are no reports of outbreaks in the Papaloapan region and hence, it seems like a relatively safe food product. However, the most common microorganisms associated with food poisoning outbreaks caused by cheese are Salmonella spp., S. aureus, Listeria monocytogenes, and enteropathogenic strains of Escherichia coli. Most of the cheeses that use raw milk are contaminated with these types of microorganisms (Paswan \& Park, 2020). Thus, their consumption must be under precaution. To keep the level of pathogens low, it could be possible to maintain a low $\mathrm{pH}$ or close to the $\mathrm{pK}_{\mathrm{a}}$ (3.86) of the lactic acid and controlling the addition of $\mathrm{NaCl}$.

Now that the microbiota has been characterized, it could be possible to suggest to the producer to prepare an inoculum with the correct concentrations of the beneficial strains of microorganisms and using pasteurized milk. Moreover, due to the nature of fresh cheeses to possess around $46 \%$ to $67 \%$ moisture (González-Córdova et al., 2016), it 
must be consumed as soon as possible after production to reduce the reproduction of the pathogen microorganisms.

In conclusion, all samples of fresh artisan cheeses were under high microbial loads. Lactic acid bacteria were in a typical load, as established by the quality and safety standards in the food industry. Conversely, pathogenic bacteria exceeded this limit. Therefore, these cheeses were not recommendable for consumption. However, among the diversity, some microorganisms of industrial importance were identified, primarily LAB, such as Streptococcus, Lactococcus, Leuconostoc, Lactobacillus, and Enterococcus. Among these microorganisms, L. lactis is essential for fresh artisan cheeses. There was no significant difference between the summer and winter seasons in the count of microorganisms. Besides, total coliforms such as Salmonella, Klebsiella, and other groups of pathogenic origin were found. PCR-DGGE method showed specific bacterial profiles for each sample in the two seasons, and there was no variability among microorganisms. Seasons, production place, as well as the manufacturing method did not affect the microbiota or the typical characteristics of this product.

\section{ACKNOWLEDGMENT}

The authors wish to thank the National Council of Science and Technology (CONACYT) for the scholarship granted to Nancy Cruz Velasco (CVU 561058) to carry out master's studies.

Thanks to the Faculty of Zootechnics and Ecology of the UACH. Special thanks to Ms. C. Ruth Lechuga and Dr. Agustín Corral for providing the necessary equipment and reagents and for their advice for the project.

\section{CONFLICT OF INTEREST}

The authors have no conflict of interest to declare.

\section{REFERENCES}

Aldrete-Tapia, Alejandro, Claudia Meyli Escobar-Ramírez, Mark L. Tamplin, and Montserrat Hernández-Iturriaga. 2018. Characterization of Bacterial Communities in Mexican Artisanal Raw Milk 'Bola de Ocosingo' Cheese by High-Throughput Sequencing. Frontiers in Microbiology 9 (October). https://doi.org/10.3389/fmicb.2018.02598

Belitz HD., Grosch W., Schieberle P. 2004. Milk and Dairy Products. In: Food Chemistry. Springer, Berlin, Heidelberg. https://doi.org/10.1007/978-3-662-07279-0 11.

Ben Said, L., Gaudreau, H., Dallaire, L., Tessier, M., \& Fliss, I. 2019. Bioprotective Culture: A New Generation of Food Additives for the Preservation of Food Quality and Safety. Industrial Biotechnology, 15(3), 138-147. https://doi.org/10.1089/ind.2019.29175.lbs 
Burin, R. C. K., Silva, A., \& Nero, L. A. 214. Influence of lactic acid and acetic acid on Salmonella spp. growth and expression of acid tolerance-related genes. Food Research International, 64, 726-732. https://doi.org/10.1016/j.foodres.2014.08.019

Castro, R. D., Oliveira, L. G., Sant'Anna, F. M., Luiz, L. M. P., Sandes, S. H. C., Silva, C. I. F., Silva, A. M., Nunes, A. C., Penna, C. F. A. M., \& Souza, M. R. 2016. Lactic acid microbiota identification in water, raw milk, endogenous starter culture, and fresh Minas artisanal cheese from the Campo das Vertentes region of Brazil during the dry and rainy seasons. Journal of Dairy Science, 99(8), 6086-6096. https://doi.org/10.3168/jds.2015$\underline{10579}$

Castro-Castillo, Gabriela, Martínez-Castañeda, Francisco Ernesto, Martínez-Campos, Ángel Roberto, \& Espinoza-Ortega, Angélica. 2013. Caracterización de la microbiota nativa del queso Oaxaca tradicional en tres fases de elaboración. Revista de la Sociedad Venezolana de Microbiología, 33(2), 105-109. Retrieved March 11, 2021, http://ve.scielo.org/scielo.php?script=sci arttext\&pid=S1315-

$25562013000200004 \& \operatorname{lng}=$ es\&tIng $=$.

Cocolin, L., Diez, A., Urso, R., Rantsiou, K., Comi, G., Bergmaier, I., \& Beimfohr, C. 2007. Optimization of conditions for profiling bacterial populations in food by cultureindependent methods. International Journal of Food Microbiology, 120(1-2), 100-109. https://doi.org/10.1016/j.ijfoodmicro.2007.06.015

Cocolin, L., Innocente, N., Biasutti, M., \& Comi, G. 2004. The late blowing in cheese: a new molecular approach based on PCR and DGGE to study the microbial ecology of the alteration process. International Journal of Food Microbiology, 90(1), 83-91. https://doi.org/10.1016/S0168-1605(03)00296-4

Cremonesi, P., Monistero, V., Moroni, P., Barberio, A., Almeida, R., Latorre, A. A., \& Castiglioni, B. 2020. Main Pathogens Detected in Milk. In Reference Module in Food Science. Elsevier. https://doi.org/10.1016/B978-0-08-100596-5.22977-6

Dahllöf, I., Baillie, H., \& Kjelleberg, S. 2000. rpoB-Based Microbial Community Analysis Avoids Limitations Inherent in 16S rRNA Gene Intraspecies Heterogeneity. Applied and Environmental Microbiology, 66(8), 3376-3380. https://doi.org/10.1128/AEM.66.8.3376$\underline{3380.2000}$

DasSarma, S., Berquist, B. R., Coker, J. A., DasSarma, P., \& Müller, J. A. 2006. Postgenomics of the model haloarchaeon Halobacterium sp. NRC-1. Saline Systems, 2, 3. https://doi.org/10.1186/1746-1448-2-3

Dehority, B. A. 1969. Pectin-fermenting bacteria isolated from the bovine rumen. Journal of Bacteriology, 99(1), 189-196. https://doi.org/10.1128/JB.99.1.189-196.1969

DOF. 2006. Diario Oficial de La Federación. NMX-F-718-COFOCALEC-2006. Sistema producto leche-alimentos-lácteos-leche y productos de leche-guía para el muestreo. 
Diario Oficial de La Federación de La SeGob. Mex. http://sidof.segob.gob.mx/notas/5469378. Retrieved March13, 2021.

Dugat-Bony, E., Sarthou, A.-S., Perello, M.-C., de Revel, G., Bonnarme, P., \& Helinck, S. 2016. The effect of reduced sodium chloride content on the microbiological and biochemical properties of a soft surface-ripened cheese. Journal of Dairy Science, 99(4), 2502-2511. https://doi.org/10.3168/jds.2015-10502

El-Gendy, A. O., Brede, D. A., Essam, T. M., Amin, M. A., Ahmed, S. H., Holo, H., Nes, I. F., \& Shamikh, Y. I. 2021. Purification and characterization of bacteriocins-like inhibitory substances from food isolated Enterococcus faecalis OS13 with activity against nosocomial enterococci. Scientific Reports, 11(1), 1-12. https://doi.org/10.1038/s41598-021-83357-z

Fraga Cotelo, M., Perelmuter Schein, K., Giacaman Salvo, S. S., Zunino Abirad, P. M., \& Carro Techera, S. B. 2013. Antimicrobial properties of lactic acid bacteria isolated from uruguayan artisan cheese. Food Science and Technology (Campinas), 33(4), 801804. https://doi.org/10.1590/S0101-20612013000400029

Godálová, Z., Kraková, L., Puškárová, A., Bučková, M., Kuchta, T., Piknová, L., \& Pangallo, D. 2016. Bacterial consortia at different wine fermentation phases of two typical Central European grape varieties: Blaufränkisch (Frankovka modrá) and Grüner Veltliner (Veltlínske zelené). International Journal of Food Microbiology, 217, 110-116. https://doi.org/10.1016/j.ijfoodmicro.2015.10.015

González-Córdova, A. F., Yescas, C., Ortiz-Estrada, Á. M., De la Rosa-Alcaraz, M. de los Á., Hernández-Mendoza, A., \& Vallejo-Cordoba, B. 2016. Invited review: Artisanal Mexican cheeses. Journal of Dairy Science, 99(5), 3250-3262. https://doi.org/10.3168/jds.2015-10103

González-Montiel, L., \& Franco-Fernández, M. J. 2015. Perfil microbiológico del queso de aro consumido en la Cañada Oaxaqueña. Brazilian Journal of Food Technology, 18(3), 250-257. https://doi.org/10.1590/1981-6723.7514

Holdeman, L. V., Cato, E. P., Burmeister, J. A., \& Moore, W. E. C. 1980. Descriptions of Eubacterium timidum sp. nov., Eubacterium brachy sp. nov., and Eubacterium nodatum sp. nov. Isolated from Human Periodontitis. International Journal of Systematic Bacteriology, 30(1), 163-169. https://doi.org/10.1099/00207713-30-1-163

Holle, M. J., Ibarra-Sánchez, L. A., Liu, X., Stasiewicz, M. J., \& Miller, M. J. 2018. Microbial analysis of commercially available US Queso Fresco. Journal of Dairy Science, 101(9), 7736-7745. https://doi.org/10.3168/jds.2017-14037

Kim, J., Kim, S. J., Kim, S. H., Kim, S. I., Moon, Y. J., Park, S. J., Kahng, H. Y., \& Chung, Y. H. 2014. Draft Genome Sequence of Sphingopyxis sp. Strain MWB1, a 
Crude-Oil-Degrading Marine Bacterium. Genome Announcements, 2(6). https://doi.org/10.1128/genomeA.01256-14

Kiskowski, M. A., Jiang, Y., \& Alber, M. S. 2004. Role of streams in myxobacteria aggregate formation. Physical Biology, 1(3), 173-183. https://doi.org/10.1088/1478$\underline{3967 / 1 / 3 / 005}$

Klaenhammer, T. R. 1988. Bacteriocins of lactic acid bacteria. Biochimie, 70(3), 337349. https://doi.org/10.1016/0300-9084(88)90206-4

Klaenhammer, T., Altermann, E., Arigoni, F., Bolotin, A., Breidt, F., Broadbent, J., Cano, R., Chaillou, S., Deutscher, J., Gasson, M., van de Guchte, M., Guzzo, J., Hartke, A., Hawkins, T., Hols, P., Hutkins, R., Kleerebezem, M., Kok, J., Kuipers, O., ... Siezen, R. 2002. Discovering lactic acid bacteria by genomics. In Lactic Acid Bacteria: Genetics, Metabolism and Applications (pp. 29-58). Springer Netherlands. https://doi.org/10.1007/978-94-017-2029-8 3

Liu, C., Finegold, S. M., Song, Y., \& Lawson, P. A. 2008. Reclassification of Clostridium coccoides, Ruminococcus hansenii, Ruminococcus hydrogenotrophicus, Ruminococcus luti, Ruminococcus productus and Ruminococcus schinkii as Blautia coccoides gen. nov., comb. nov., Blautia hansenii comb. nov., Blautia hydroge. International Journal Of Systematic and Evolutionary Microbiology, 58(8), 1896-1902. https://doi.org/10.1099/ijs.0.65208-0

Luiz, L. M. P., Castro, R. D., Sandes, S. H. C., Silva, J. G., Oliveira, L. G., Sales, G. A., Nunes, A. C., \& Souza, M. R. 2016. Isolation and identification of lactic acid bacteria from Brazilian Minas artisanal cheese. CyTA - Journal of Food, 1-4. https://doi.org/10.1080/19476337.2016.1219392

Martínez-López, V., Del Moral Ventura, S. T., Sachman Ruiz, B., Ramírez-Coutiño, L. P., \& García-Gómez, M. D. J. 2016. Dinámica poblacional y aislamiento de bacterias ácido lácticas en lactosuero fermentado. Nova Scientia, 8(17), 326. https://doi.org/10.21640/ns.v8i17.522

Moser, A., Schafroth, K., Meile, L., Egger, L., Badertscher, R., \& Irmler, S. 2018. Population Dynamics of Lactobacillus helveticus in Swiss Gruyère-Type Cheese Manufactured With Natural Whey Cultures. Frontiers in Microbiology, 9. https://doi.org/10.3389/fmicb.2018.00637

Nakazawa, F., Sato, M., Poco, S. E., Hashimura, T., Ikeda, T., Kalfas, S., Sundqvist, G., \& Hoshino, E. 2000. Description of Mogibacterium pumilum gen. nov., sp. nov. and Mogibacterium vescum gen. nov., sp. nov., and reclassification of Eubacterium timidum (Holdeman et al. 1980) as Mogibacterium timidum gen. nov., comb. nov. International Journal of Systematic and Evolutionary Microbiology, 50(2), 679-688. https://doi.org/10.1099/00207713-50-2-679 
Paswan, R., \& Park, Y. W. 2020. Survivability of Salmonella and Escherichia coli O157:H7 Pathogens and Food Safety Concerns on Commercial Powder Milk Products. Dairy, 1(3), 189-201. https://doi.org/10.3390/dairy1030014

Popović-Vranješ, A., Paskaš, S., Becskei, Z., Jevtić, M., \& Krstović, S. 2018. The Impact of Organic Agriculture on Biodiversity Conservation and Milk Quality for Traditional Cheese Production. Contemporary Agriculture, 67(1), 58-64. https://doi.org/10.2478/contagri-2018-0009

Porwollik, S., Boyd, E. F., Choy, C., Cheng, P., Florea, L., Proctor, E., \& McClelland, M. 2004. Characterization of Salmonella enterica Subspecies I Genovars by Use of Microarrays. Journal of Bacteriology, 186(17), 5883-5898. https://doi.org/10.1128/JB.186.17.5883-5898.2004

Ruvalcaba-Gómez, J. M., Delgado-Macuil, R. J., Zelaya-Molina, L. X., Maya-Lucas, O., Ruesga-Gutiérrez, E., Anaya-Esparza, L. M., Villagrán-de la Mora, Z., López-de la Mora, D. A., \& Arteaga-Garibay, R. I. 2020. Bacterial Succession through the Artisanal Process and Seasonal Effects Defining Bacterial Communities of Raw-Milk Adobera Cheese Revealed by High Throughput DNA Sequencing. Microorganisms, 9(1), 24. https://doi.org/10.3390/microorganisms9010024

Sánchez-Juanes, F., Teixeira-Martín, V., González-Buitrago, J. M., Velázquez, E., \& Flores-Félix, J. D. 2020. Identification of Species and Subspecies of Lactic Acid Bacteria Present in Spanish Cheeses Type "Torta" by MALDI-TOF MS and pheS gene Analyses. Microorganisms, 8(2), 301. https://doi.org/10.3390/microorganisms8020301

SIAP. 2019. Servicio de Información Agroalimentaria y Pesquera. Boletín de Leche, 67. http://infosiap.siap.gob.mx/opt/boletlech/Boletin leche cuarto trimestre final paginas.pdf. Retrieved March13, 2021.

Stiles, M. E., \& Holzapfel, W. H. 1997. Lactic acid bacteria of foods and their current taxonomy. International Journal of Food Microbiology, 36(1), 1-29. https://doi.org/10.1016/S0168-1605(96)01233-0

Tadjine, D. S., Boudalia, S., Bousbia, A., Khelifa, R., Boudechiche, M. L., Tadjine, A., \& Chemmam, M. 2020. Pasteurization effects on yield and physicochemical parameters of cheese in cow and goat milk. Food Science and Technology, 40(3), 580-587. https://doi.org/10.1590/fst.13119

Torres-Llanez, M. J., Vallejo-Cordoba, B., Díaz-Cinco, M. E., Mazorra-Manzano, M. A., \& González-Córdova, A. F. 2006. Characterization of the natural microflora of artisanal Mexican Fresco cheese. Food Control, 17(9), 683-690. https://doi.org/10.1016/i.foodcont.2005.04.004 
Vos, P., Garrity, G., Jones, J. D., Krieg, N. R., Wolfgang, L., Fred, A., Karl-Heinz, S., \& William, B. W. (Eds.). 2011. The Firmicutes. In Bergey's Manual of Systematic Bacteriology (2nd. Ed., p. 1450). Springer Science \& Business Media

Walter, J., Tannock, G. W., Tilsala-Timisjarvi, A., Rodtong, S., Loach, D. M., Munro, K., \& Alatossava, T. 2000. Detection and Identification of Gastrointestinal Lactobacillus Species by Using Denaturing Gradient Gel Electrophoresis and Species-Specific PCR Primers. Applied and Environmental Microbiology, 66(1), 297-303. https://doi.org/10.1128/AEM.66.1.297-303.2000

Yeluri Jonnala, B. R., McSweeney, P. L. H., Sheehan, J. J., \& Cotter, P. D. 2018. Sequencing of the Cheese Microbiome and Its Relevance to Industry. Frontiers in Microbiology, 9. https://doi.org/10.3389/fmicb.2018.01020 